\title{
PERAMALAN JUMLAH KEDATANGAN WISATAWAN MANCANEGARA DENGAN MENGGUNAKAN METODE TIME INVARIANT FUZZY TIME SERIES (STUDI KASUS : WISATA KABUPATEN PASURUAN)
}

\author{
Cahya Rahmad ${ }^{1}$, Moch. Febry Ramadhani², Dwi Puspitasari ${ }^{3}$ \\ 1,2,3 Jurusan Teknologi Informasi, Program Studi Teknik Informatika, Politeknik Negeri Malang \\ 1'cahya.rahmad@polinema.ac.id, ${ }^{2}$ febryramadhani02@gmail.com, ${ }^{3}$ dwi_sti@yahoo.com
}

\begin{abstract}
Abstrak
Wilayah provinsi Jawa Timur merupakan wilayah yang mempunyai banyak destinasi tempat wisata yang mengundang para wisatawan mancanegara untuk berkunjung ke jawa timur, salah satunya di Kabupaten Pasuruan. Dinas Pariwisata dan Kebudayaan Kabupaten Pasuruan sendiri memiliki data bulanan jumlah wisatawan mancanegara yang berkunung ke tempat wisasta di Kabupaten Pasuruan setiap tahun, hal tersebut memungkinkan untuk dilakukannya peramalan jumlah kunjungan wisatawan mancanegara untuk bulan kedepannya.

Sistem peramalan dengan menggunakan fuzzy time series menangkap pola dari data lampau kemudian digunakan untuk menampilkan data yang akan datang. Dalam perhitungan peramalan dengan menggunakan fuzzy time series, panjang interval ditentukan pada awal proses pehitungan. Penentuan panjang interval akan berpengaruh dalam pembentukan fuzzy relationship yang akan memberikan dampak perbedaan hasil pehitungan peramalan. Salah satu metode dalam penentuan panjang interval yang efektif adalah dengan menggunakan metode berbasis rata-rata atau average-based fuzzy time series. Dalam penelitian, penulis mengimplementasikan metode fuzzy time series untuk meramalkan data kunjungan wisatawan mancanegara tiap bulan, adapun data yang digunakan untuk pengujian adalah data yang berasal dari Dinas Pariwisata dan Kebudayaan Kabupaten Pasuruan. Dari hasil pengujian yang dilakukan pada 4 destinasi wisata, diketahui bahwa peramalan menggunakan metode fuzzy time series dengan fuzzy set berbasis rata-rata didapatkan nilai Avarage Forecasting Error Rate (AFER) pada destinasi wisata Bromo hasil terbaik sebesar 25,1131\% dengan 12 data latih (1 tahun), pada destinasi wisata Kaliandra hasil terbaik sebesar 50,4043\% dengan 48 data latih (4 tahun), dan pada destinasi wisata Taman Safari Indonesia II hasil terbaik sebesar 21,8504\% dengan 12 data latih (1 tahun), serta pada destinasi wisata Kebun Raya Purwodadi hasil terbaik sebesar 70,6283\% dengan 12 data latih (1 tahun).
\end{abstract}

Kata kunci : Peramalan, Pariwisata, Time Invariant, Fuzzy Time Series

\section{Pendahuluan}

Pariwisata dianggap sebagai suatu aset yang strategis untuk mendorong pembangunan pada wilayah-wilayah tertentu yang mempunyai potensi objek wisata. Perkembangan pariwisata merupakan aktivitas yang pada akhirnya memberi pengaruh ekonomi terhadap kehidupan di sekitar lokasi pariwisata, pengaruh ekonomi dapat dirasakan oleh masyarakat sekitar, terutama dari segi ekonomi yaitu meningkatkan pendapatan. Keuntungan lainnya adalah dengan dibangunnya sarana-sarana kemudahan menuju lokasi pariwisata, misalnya transportasi dan kios-kios penjualan sehingga dapat membuka lapangan pekerjaan bagi masyarakat (Rizky, 2014).

Beberapa faktor yang memengaruhi wisatawan mancanegara berkunjung ke suatu wilayah negara, seperti nilai tukar mata uang, inflasi disuatu wilayah kunjungan wisatawan, dan letak geografis suatu wiyalah negara. Semakin besar nilai tukar mata uang suatu negara terhadap rupiah, maka kecenderungan warga negara tersebut untuk berkunjung ke Indonesia semakin besar. Letak geografis atau jarak juga menjadi salah satu faktor yang menentukan jumlah wisatawan asing ke Surabaya.

Peningkatan yang tidak terduga pada jumlah kunjungan wisatawan ini dapat berdampak kesulitan bagi para pelaku wisatawan dalam hal memberikan pelayanan terbaik dan sebaliknya jika terjadi penurunan jumlah kunjungan wisatawan hal yang dikhawatirkan akan berdampak pada sektor perekonomian masyarakat yang jika terjadi pada waktu yang terus menerus dikhawatirkan akan terjadi peningkatan pengangguran.

Untuk itu diperlukan suatu peramalan yang dapat memberikan informasi atau gambaran pada proses jumlah kunjungan wisatawan mancangera. Peramalan (forecasting) adalah seni dan ilmu untuk memperkirakan kejadian di masa depan. Hal ini dapat dilakukan dengan melibatkan pengambilan data masa lalu dan menempatkannya ke masa yang akan datang dengan suatu bentuk model yang matematis, dan bisa juga dalam bentuk prediksi 
intuisi yang bersifat subjektif. Ataupun bisa juga dengan menggunakan kombinasi model matematis yang disesuaikan, sehingga metode peramalan banyak sekali yang sudah dikembangkan seperti metode fuzzy time series.

\section{Tinjauan Pustaka}

\subsection{Time Invariant Fuzzy Time Series}

\subsubsection{Peramalan Data dengan Time Series}

Jika terdapat relasi fuzzy $R(t, t-1)$ sehingga $F(t)$ $=F(t-1) \times \mathrm{R}(t, t-1)$ pengertian pada symbol $\mathrm{x}$ adalah suatu operator maka $F(\mathrm{t})$ disebabkan oleh $F(t-1)$. Relasi yang berada pada $F(\mathrm{t})$ dan $F(t-1)$ dinotasikan oleh $F(t-1)->F(\mathrm{t})$.

\subsubsection{Group Relasi Fuzzy Logic}

Relasi Fuzzy Logic dengan sisi kiri yang sama, akan menjadikan suatu grup yang sama yaitu group relasi fuzzy logic. Contohnya sebagai berikut: Untuk sisi kiri $A_{\mathrm{t}}$ yang sama, maka terdapat pernyataan persamaan grup sebagai berikut:

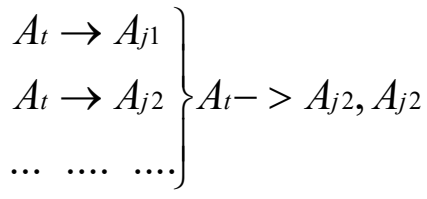

\subsubsection{Operator pada Time Invariant Fuzzy Time Series}

Jika $F(t)$ disebabkan oleh $F(t-1)$ akan dinotasikan dengan $F(t-1)->F(t)$ maka relasinya menyatakan dengan $F(t)=F(t-1){ }^{\circ} \mathrm{R}(t, t-1)$, symbol - berartikan operator max - min dan $\mathrm{R}(t, t-1)$ merupakan model orde satu dari $F(t)$.

\subsubsection{Defuzzifikasi}

Defuzziifikasi merupakan cara untuk mendapatkan nilai tegas (crisp) dari himpunan fuzzy, adapun prosesnya sebagai berikut:

- Jika terdapat semua nilai nol, maka variasi peramalannya adalah 0 .

- Jika nilai keanggotaan dari outputnya memiliki satu max, maka titik tengah intervalnya dimana nilai ini dapat dicapai adalah variasi peramalan.

- Jika nilai keanggotannya dari outputnya memiliki dua atau lebih max yang berurutan, maka titik tengah interval dimana nilai ini dicapai adalah variasi peramalannya.

Selain itu dengan menggunakan centroid, seperti yang ditunjukkan pada persamaan berikut ini.

$$
Z=\frac{\sum x A}{\sum A}
$$

$A$ merupakan suatu luasan yang memiliki titik berat $\mathrm{x}$.
Metode Time Invariant Fuzzy Time Series merupakan suatu metode yang memilik 2 aspek penting, diantarannya adalah dapat menggunakan variasi data historisnya dari pada karakteristik pendaftaran sebenarnya dan perhitungan relasi $R(t, t-$ 1) yang akan digunakan untuk memprediksi peramalan masa depan. Berikut ini merupakan langkah-langkah proses peramalan:

1. Mendefinisikan himpunan semesta $U$ dari variasi data historis, yang menggunakan jumlah himpunan fuzzy (fuzzy set) yang ditentukan oleh user. Kemudian $U$ dipartisi menjadi sejumlah interval yang sama panjang dan mndefinisikan himpunan fuzzy $\mathrm{A}_{\mathrm{i}}$.

2. Menfuzzifikasikan suatu nilai variasi dari sebuah data.

3. Menyatakan relasi orde1 dari variasi fuzzy logic $A_{i}->A_{J}$ dan menjadikan relasi fuzzy orde1 yang menjadikan suatu grup relasi fuzzy logic jika memiliki sisi kiri yang sama kemudian menghitung relasi logic $R_{i}$ untuk setiap fuzzy ke- $i$ dan mendapatkan nilai output peramalannya.

4. Menghitung suatu nilai ouput yang permalannya dengan proses deffuzifikasi dan dapat menghitung peramalan pendaftarannya (Sah, 2005).

\subsection{Menghitung Error Peramalan}

Teknik dalam peramalan tidak selamanya akan mendapatkan hasil yang tepat karena metode yang digunakan dalam suatu peramalan belum tentu sesuai dengan sifat datanya. Perlu adanya pengawasan dalam meramalkan suatu data yang nantinya dapat diketahui sesuai atau tidaknya metode peramalan yang telah digunakan, sehingga nantinya akan dipilih dan ditentukan metode peramalan yang lebih sesuai dengan cara menentukan batas toleransi peramalan atas ke tidak akurasian yang terjadi (Jumingan, 2009).

Prinsip pengawasan pada suatu peramalan dilakukan dengan cara membandingkan hasil peramalan dengan hasil kenyataan yang terjadi. Penggunaan teknik peramalan yang menghasilkan penyimpangan terkecil merupakan teknik peramalan yang paling sesuai untuk digunakan (Jumingan, 2009).

Metode AFER (Average Forecasting Error Rate) digunakan untuk mengetahui bersarnya kesalahan yang terjadi pada data hasil peramalan terhadap data actual. Berikut merupakan persamaan tentang cara perhitungan AFER (Jilani, 2007).

$\mathrm{AFER}=\frac{\left|\mathrm{A}_{\mathrm{i}}-\mathrm{F}_{\mathrm{i}}\right| / \mathrm{A}_{\mathrm{i}}}{\mathrm{n}} \times 100 \%$

Pada perhitungan AFER $A_{i}$ merupakan nilai data actual pada data ke-i dan $F_{i}$ merupakan nilai hasil peramalan untuk data ke-i. Adapun n merupakan banyaknya dari suatu data dan bilangan 
$100 \%$ merupakan nilai untuk mendapatkan hasil persentase. Nilai AFER adalah nilai yang menyatakan persentase selisih antara data prediksi dengan data actual. Dengan nilai error yang semakin kecil maka tingkat keakurasian dapat dikatakan semakin baik (Rahmadiani, 2012)

Tabel 1. Kriterian Penilaian AFER

\begin{tabular}{|c|c|}
\hline AFER & Pengertian \\
\hline$<10 \%$ & Sangat baik \\
\hline $10 \%-20 \%$ & Baik \\
\hline $20 \%-50 \%$ & Cukup \\
\hline$>50 \%$ & Buruk \\
\hline
\end{tabular}

\section{Perancangan dan Implementasi}

\subsection{Perancangan Sistem}

Pada bagian perancangan sistem ini terdapat rancangan yang mendukung jalannya alur sistem maupun alur perhitungan metode yang di gunakan. Untuk gambaran umum sistem yang berjalan dapat di lihat pada Gambar 1, alur gambaran umum tersebut dimulai dari proses import data, dan kemudian data masuk ke dalam database, lalu data dapat dilihat pada program dan pada progam dapat dilakukan proses perhitungan peramalan yang mengeluarkan data hasil peramalan, serta pada program juga dapat menampilkan grafk dari perbandingan data aktual dan data hasil peramalan. Untuk flowchart alur sistem dapat di lihat pada Gambar 2 dan untuk flowchart alur perhitungan metode dapat di lihat pada Gambar 3.

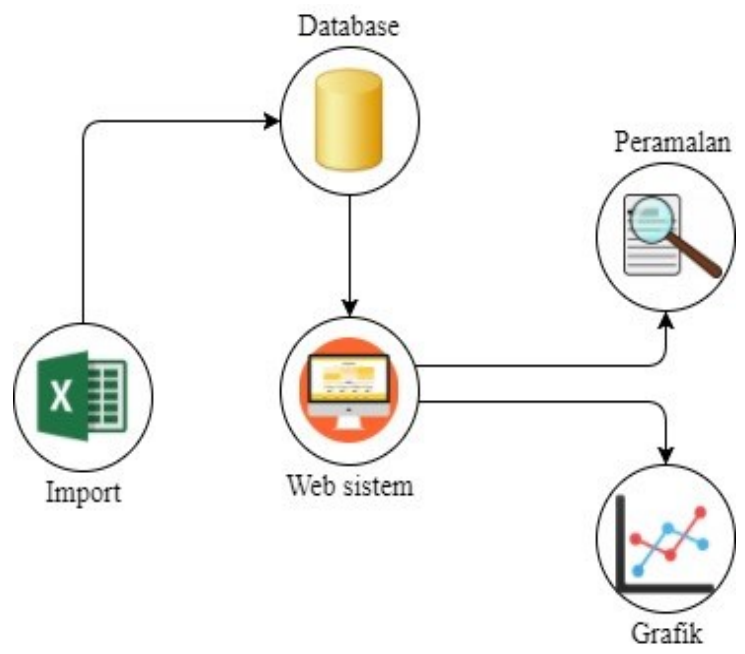

Gambar 1. Block Diagram

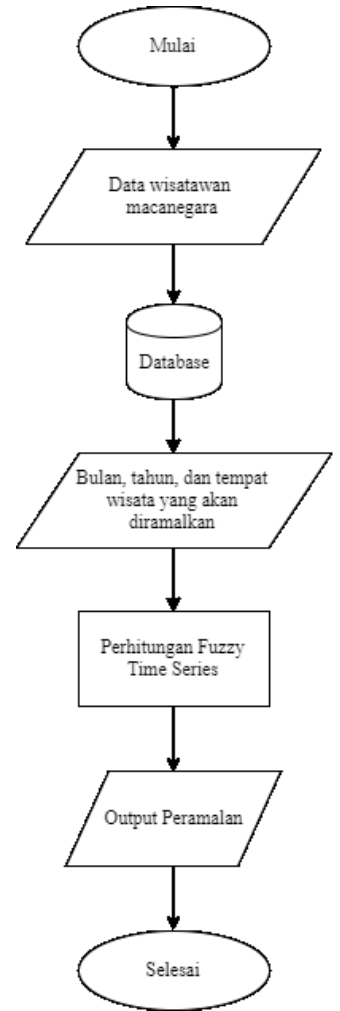

Gambar 2. Flowchart Alur Sistem 


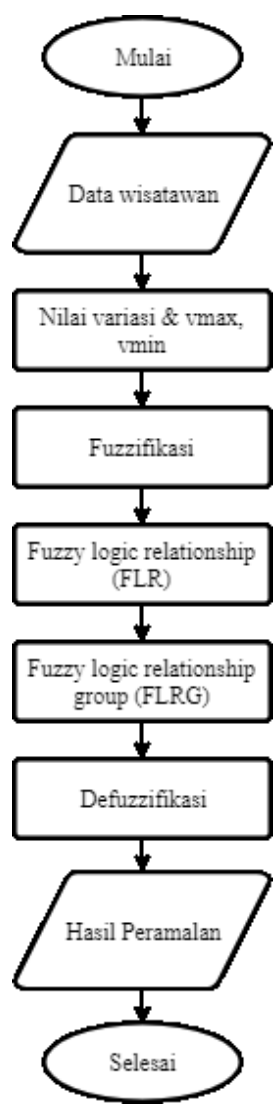

Gambar 3. Flowchart Perhitungan Metode

\subsection{Use Case Diagram}

Struktur menu pada aplikasi sistem pendukung keputusan kebutuhan wisatawan dengan menggunakan metode fuzzy Sugeno dirancang khusus berbasis web dengan pemrograman PHP. Diagram use case mendeskripsikan sebuah interaksi antara satu atau lebih aktor dengan sistem yang akan dibuat.

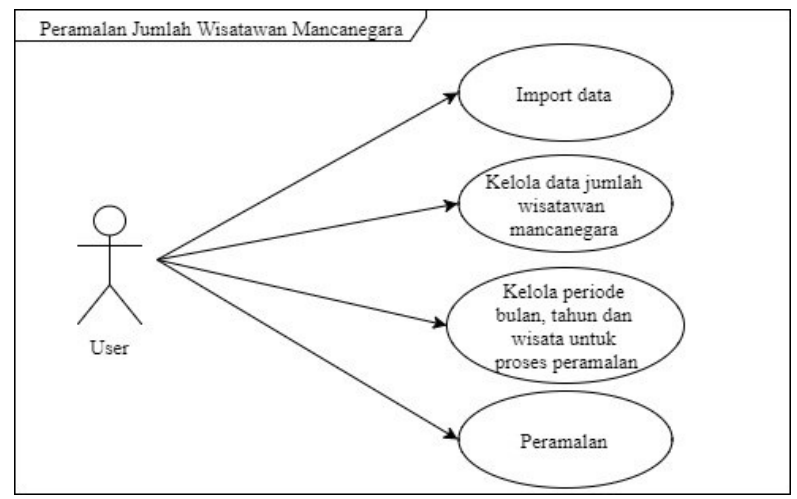

Gambar 4. Use Case Diagram

\section{Pengujian dan Pembahasan}

Dalam uji coba pembahasan ini, untuk mengetahui nilai hasil peramalan dengan berbasis rata-rata dan nilai AFER untuk peramalan pada bulan yang ingin diramalkan. Data yang digunakan dalam pengujian ini adalah data dari Dinas Pariwisata dan Kebudayaan Kabupaten Pasuruan tepatnya adalah data jumlah kunjungan wisatawan mancanegara di Bromo, Kaliandra, Taman Safari Indonesia 2 dan Kebun Raya Purwodadi. Data yang digunakan yaitu data dari bulan januari 2011 sampai bulan desember 2011 dengan data 1 tahun sebanyak 12 data, dari bulan januari 2011 sampai bulan desember 2012 dengan data 2 tahun sebanyak 24 data, dari bulan januari 2011 sampai bulan desember 2013 dengan data 3 tahun sebanyak 36 data, dari bulan januari 2011 sampai bulan desember 2014 dengan data 4 tahun sebanyak 48 data, dari bulan januari 2011 sampai bulan desember 2015 dengan data 5 tahun sebanyak 60 data, dan dari bulan januari 2011 sampai bulan desember 2016 dengan data 6 tahun sebanyak 72 data.

Kemudian untuk mengetahui hasil dari perbandingan antara data aktual dan data hasil peramalan serta nilai AFER sampai dengan januari 2016, digunakan parameter berbasis rata-rata dalam menentukan fuzzy set.

\subsection{Wisata Bromo}

Dari hasil perhitungan pengujian pada wisata Bromo dengan menggunakan 12, 24, 36, 48, 60, dan 72 data latih pada peramalan sampai dengan desember 2016 dengan menggunakan fuzzy set berbasis rata-rata didapatkan nilai rata-rata AFER 25,1131\% untuk 12 data latih (1 tahun), 35,1042\% untuk 24 data latih (2 tahun), 52,9860\% untuk 36 data latih (3 tahun), 61,9842\% untuk 48 data latih (4 tahun), 65,4677\% untuk 60 data latih (5 tahun), dan $70,9980 \%$ untuk 72 data latih (6 tahun).

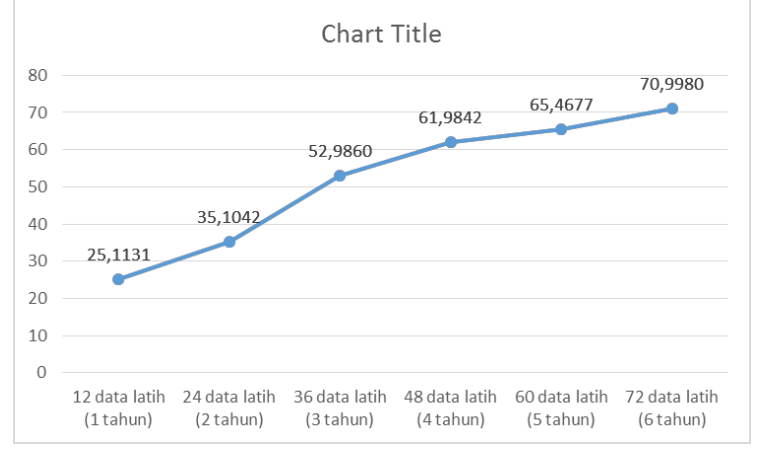

Gambar 5. Grafik Pengaruh Data Latih Terhadap AFER pada wisata Bromo dari bulan Januari 2011 hingga desember 2016

\subsection{Wisata Kaliandra}

Dari hasil perhitungan pengujian pada wisata Kaliandra dengan menggunakan 12, 24, 36, 48, 60, dan 72 data latih pada peramalan sampai dengan desember 2016 dengan menggunakan fuzzy set berbasis rata-rata didapatkan nilai rata-rata AFER $57,5265 \%$ untuk 12 data latih (1 tahun), 55,7602\% untuk 24 data latih (2 tahun), 52,7625\% untuk 36 
data latih (3 tahun), 50,4043\% untuk 48 data latih (4 tahun), 120,8056\% untuk 60 data latih (5 tahun), dan $114,3437 \%$ untuk 72 data latih (6 tahun).

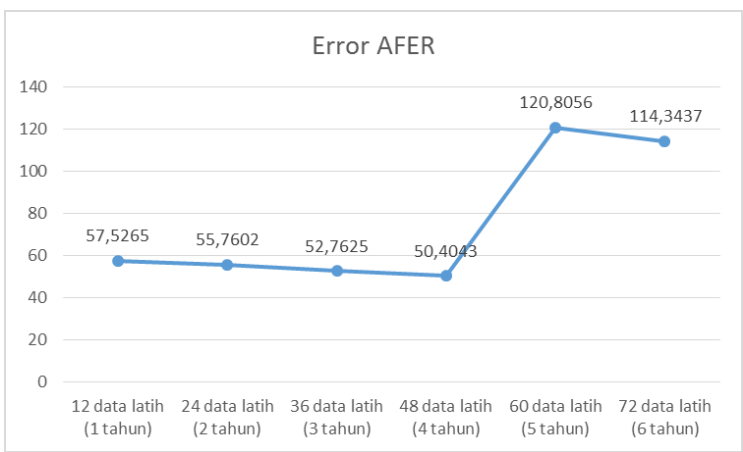

Gambar 6. Grafik Pengaruh Data Latih Terhadap

AFER pada wisata Kaliandra dari bulan Januari 2011 hingga desember 2016

\subsection{Wisata Taman Safari Indonesia II}

Dari hasil perhitungan pengujian pada wisata Taman Safari Indonesia II dengan menggunakan 12, $24,36,48,60$, dan 72 data latih pada peramalan sampai dengan desember 2016 dengan menggunakan fuzzy set berbasis rata-rata didapatkan nilai rata-rata AFER 21,8504\% untuk 12 data latih (1 tahun), 49,5876\% untuk 24 data latih (2 tahun), $56,5658 \%$ untuk 36 data latih ( 3 tahun), 44,6462\% untuk 48 data latih (4 tahun), 43,6494\% untuk 60 data latih (5 tahun), dan $45,2257 \%$ untuk 72 data latih (6 tahun).

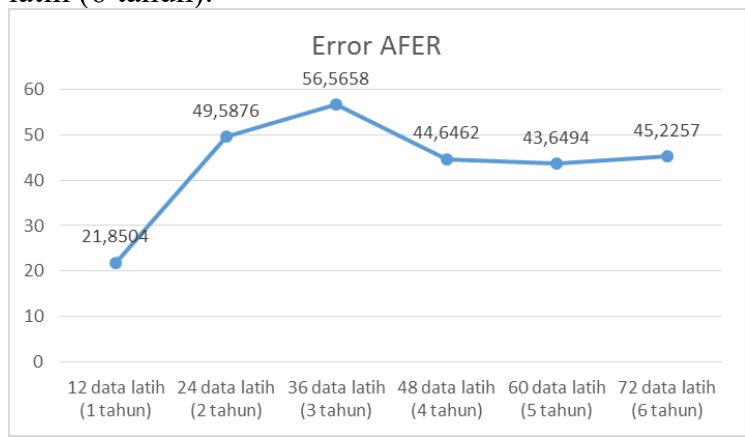

Gambar 7. Grafik Pengaruh Data Latih Terhadap AFER pada wisata Taman Safari Indonesia II dari bulan Januari 2011 hingga desember 2016

\subsection{Wisata Kebun Raya Purwodadi}

Dari hasil perhitungan pengujian pada wisata Kebun Raya Purwodadi dengan menggunakan 12, $24,36,48,60$, dan 72 data latih pada peramalan sampai dengan desember 2016 dengan menggunakan fuzzy set berbasis rata-rata didapatkan nilai rata-rata AFER 70,6283\% untuk 12 data latih (1 tahun), 86,4350\% untuk 24 data latih (2 tahun), $87,3579 \%$ untuk 36 data latih (3 tahun), 105,6130\% untuk 48 data latih (4 tahun), 90,8880\% untuk 60 data latih (5 tahun), dan $82,4920 \%$ untuk 72 data latih (6 tahun).

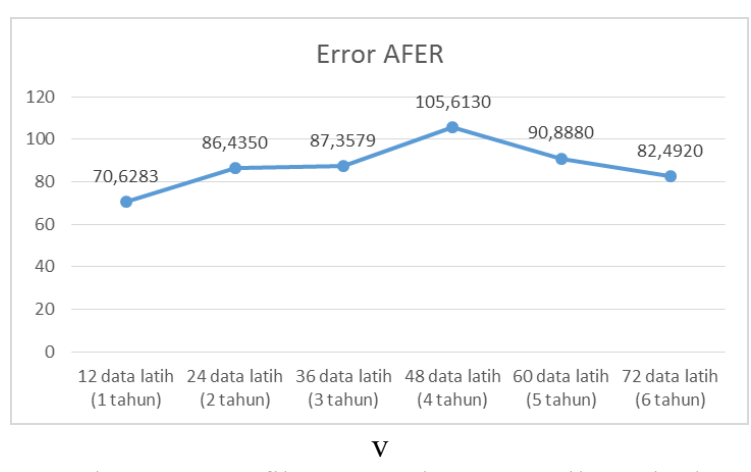

Gambar 4. 1 Grafik Pengaruh Data Latih Terhadap AFER pada wisata Kebun Raya Purwodadi dari bulan Januari 2011 hingga desember 2016

\subsection{Hasil Analisa}

Berdasarkan 4 pengujian yang telah dilakukan di atas yaitu pada wisata Bromo, Kaliandra, Taman Safari Indonesia II, dan Kebun Raya Purwodadi diketahui dari grafik data pengunjung menunjukkan pola data yang kebanyakan memiliki pola data acak dari 6 tahun data dan hanya beberapa data saja yang memiliki pola seperti pola musiman. Berdasarkan pengujian diatas dihasilkan bahwa semakin banyak data latih yang digunakan hasil AFER cenderung meningkat, dan dari hasil analisa metode ini kurang cocok digunakan untuk data yang bernilai kurang dari 100 , serta penurunan yang drastis pada data atau selisih di tiap datanya. Hal tersebut dapat menyebabkan nilai antara vmin dan vmax terlampau jauh yang akan mempengaruhi penentuan nilai fuzzy set atau interval berbasis rata-rata.

Dari hasil perhitungan yang telah dilakukan membuktikan semakin banyak data latih yang digunakan hasil AFER semakin meningkat, yang artinya tingkat akurasi data hasil peramalan terhadap data aktual semakin menurun.

\section{Kesimpulan dan Saran}

\subsection{Kesimpulan}

Berdasarkan pembahasan yang telah dilakukan pada bab 1 hingga bab 6, maka dapat disimpulkan bahwa :

a. Penelitian ini berhasil mengembangkan aplikasi peramalan pada kunjungan wisatawan mancanegara yang masuk ke wisata di wilayah Kabupaten Pasuruan dengan menggunakan metode Fuzzy Time Series.

b. Pengujian nilai akurasi peramalan dengan menggunakan metode Fuzzy Time Series ini tidak cocok jika digunakan untuk meramalkan data dalam jumlah banyak dan penggunaan data yang kurang stabil pada naik turunnya data.

c. Perhitungan metode dari aplikasi dan excel mengeluarkan hasil yang hampir sama.

\subsection{Saran}


Untuk penelitian selanjutnya, diharapkan menggunakan data dengan pola data musiman atau menggunakan data yang stabil terhadap naik turunnya data, serta dapat juga membandingkan keakuratan metode Fuzzy Time Series ini dengan metode lain untuk mencari kesalahan terkecil, atau dapat juga menggabungkan dengan metode lain Algoritma Genetika atau Particle Swarm Optimation untuk meminimalisir kesalahan

\section{Daftar Pustaka :}

Rizky, V. M. dan E. Suhartini, Eksistensi Pariwisata Songa Adventure dan Perubahan Sosial Masyarakat Condong Kabupaten Probolinggo, Jember, Universitas Jember, 2014

Sah, Melike \& Degtiarev, Konstantin Y, "Forecasting Enrollment Model Based on First Order Fuzzy Time Series”, MIEEE, 2005

Jumingan, Studi Kelayakan Bisnis - Teori dan Pembuatan Proposal Kelayakan, Jakarta, Bumi Aksara, 2009

T. A. Jilani, S. M. A., Burney, C., Ardil, Fuzzy Metric Approach for Fuzzy Time Series Forecasting based on Frequency Density Based Partitioning. Proceedings of World Academy of Science, Engineering and Technology, Vol. 2, pp. 333-338, 2007

Rahmadiani, Ani \& Wiwik Anggraeni, Implementasi Fuzzy Neural Network untuk Memperkirakan Jumlah Kunjungan Pasien Poli Bedah di Rumah Sakit Onkologi Surabaya, Vol. 1, Institut Teknologi Sepuluh November, 2012 